\title{
Origin of Horticulture in Southeast Asia and the Dispersal of Domesticated Plants to the Pacific Islands by Polynesian Voyagers: The Hawaiian Islands Case Study
}

\author{
Robert F. Bevacqua ${ }^{1}$ \\ Honolulu Botanical Gardens, 50 North Vineyard Boulevard, Honolulu, HI 96817
}

In the islands of Southeast Asia, following the Pleistocene or Ice ages, the ancestors of the Polynesians began voyages of exploration into the Pacific Ocean (Fig. 1) that resulted in the settlement of the Hawaiian Islands in A.D. 300 (Bellwood, 1987; Finney, 1979; Irwin, 1992; Jennings, 1979; Kirch, 1985). These skilled mariners were also expert horticulturists, who carried aboard their canoes many domesticated plants that would have a dramatic impact on the natural environment of the Hawaiian Islands and other areas of the world.

The exploration and colonization of the Hawaiian Islands by Polynesian voyagers was one of the most remarkable episodes of human prehistory (Irwin, 1992). These seafarers had no writing systems to record their route, no metal, no devices for measuring time, no navigational instruments, and no prior knowledge of island geography (Irwin, 1992). Yet, their trans-Pacific voyage of discovery was accomplished at least 1000 years before the transAtlantic voyages of Christopher Columbus that began in A.D. 1492. Research by archaeologists (Bellwood, 1987; Jennings, 1979; Kirch, 1985) and botanists (Abbott, 1992; Fosberg, 1991; Whistler, 1991; ) indicates one of the Polynesians most enduring achievements was the dispersal of an assemblage of horticultural plants that transformed the natural environment of both the Hawaiian Islands and much of the world's tropical regions.

\section{ORIGIN OF HORTICULTURE IN SOUTHEAST ASIA}

The prevailing view among modern horticulturists is that the discipline originated among the early civilizations of the "fertile crescent"-

Received for publication 22 Nov. 1993. Accepted for publication $22 \mathrm{Feb}$. 1994. I gratefully acknowledge the thorough manuscript review by Dorian L. Travers, educational specialist for Sea Grant at Univ. of Hawaii, and Rosalind J. Young, recreation district supervisor for the City and County of Honolulu. Bevacqua's professional interests combine archaeology and horticulture. He has conducted archaeological excavations in Southeast Asia, Australia, and the Pacific Islands to reconstruct the dispersal of people and plants to other regions of the Pacific Ocean. He also has 10 years of experience in research and extension of tropical crops, such as banana and sugar cane, that were dispersed by Polynesian navigators. Currently, he is an active member of Honolulu Canoe Club, an organization dedicated to perpetuating the Polynesian seafaring traditions through outrigger canoe racing. The cost of publishing this paper was defrayed in part by the payment of page charges. Under postal regulations, this paper therefore must be hereby marked advertisement solely to indicate this fact.

${ }^{1}$ Assistant Director. the valleys of the Euphrates, Tigris, and Nile rivers-and that the first horticultural crops were figs, dates, grapes, olives, lettuce, onions, cucumbers, and melons (Halfacre and Barden, 1979; Janick, 1979). The Greek, Roman, and European civilizations refined plant cultivation until it evolved into the discipline we recognize as horticulture today (Halfacre and Barden, 1979; Janick, 1979).

An opposing view associates the beginning of horticulture with early Chinese civilization in Asia (Solheim, 1972). Chang (1976) identifies two centers of plant domestication in eastern Asia: North China, the origin of cereal crops such as millet [Pennisetum americanum (L.) Lecke] and other sexually reproduced plants, and Southeast Asia, an earlier center for vegetatively propagated root,$$
\text { plants expanded into a horticultural }
$$

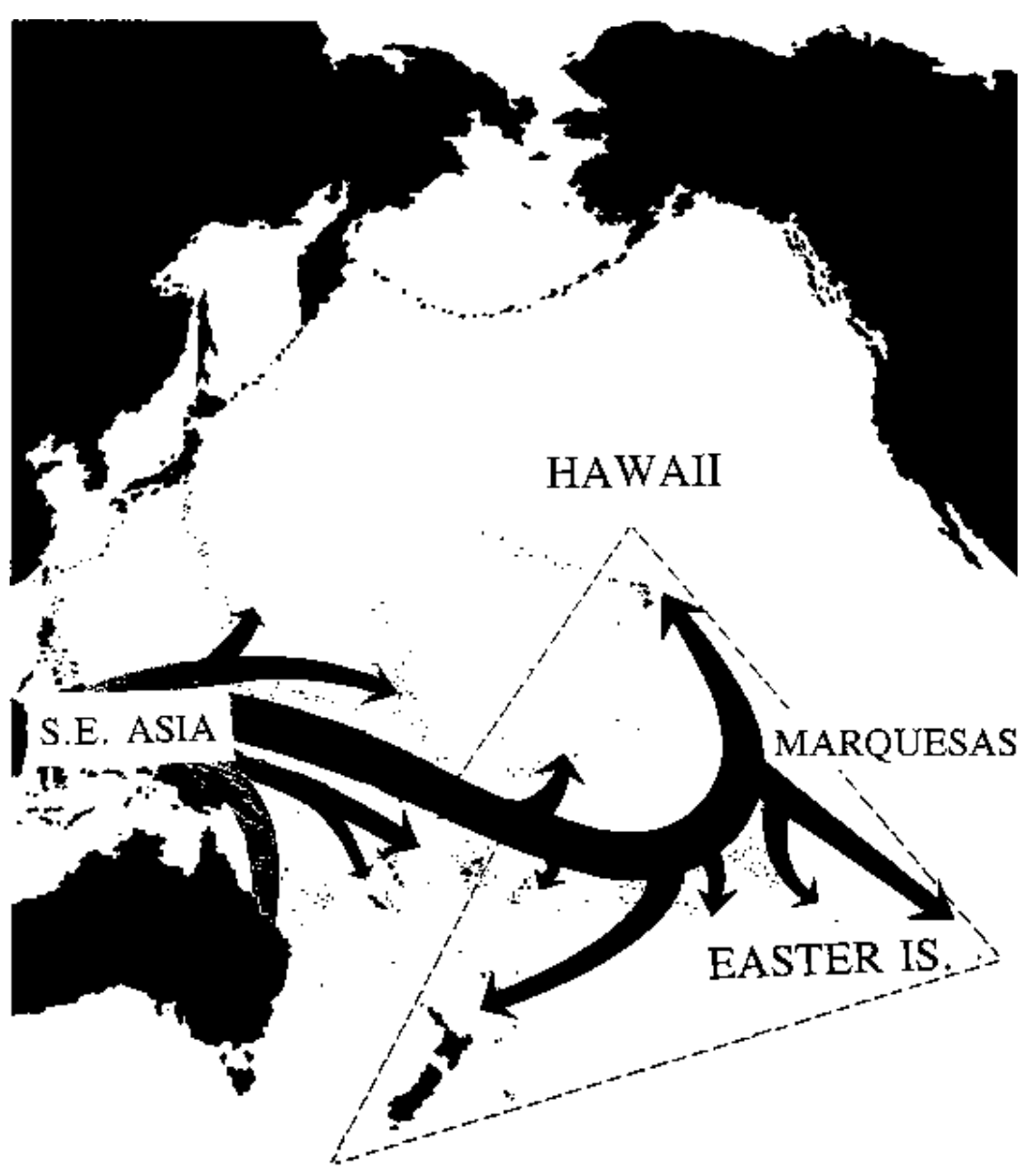

NEW ZEALAND

Fig. 1. The introduction of horticulture to the Hawaiian Islands by Polynesian voyagers in A.D. 300 represents the culmination of eastward voyages of discovery by navigators whose origins were in Southeast Asia and who dispersed an important assemblage of horticultural crops throughout the Pacific Islands. [Map adapted from Lindo and Mower (1980).] 
semblage that contained plants grown for food, clothing, housing, medicine, beauty, and fish poison.

\section{DISPERSAL OF HORTICULTURAL PLANTS TO THE PACIFIC ISLANDS}

The fishers evolved into skilled navigators, who embarked on eastward migrations (Fig. 1) that would transport their collection of tropical and subtropical plants to distant lands (Kirch, 1985). Their eastward expansion began as island hopping through insular Southeast Asia but gradually developed into longdistance voyaging. They became the ancestors of the Polynesians, brown-skinned islanders who would settle a vast triangle in the Pacific Ocean formed by the islands of Hawaii, New Zealand, and Easter Island (Fig. 1). The triangle covers an area twice that of the continental United States and contains groups of widely separated islands, such as Tonga, Samoa, Tahiti, and the Marquesas.

The exploration and colonization of the Pacific Islands by these prehistoric mariners has been reconstructed with archaeological, botanical, and linguistic evidence (Bellwood, 1987; Irwin, 1992; Jennings, 1979; Kirch, 1985). In Polynesia, the voyagers first settled Samoa and Tonga and then moved on to the Marquesas Islands, from which they set out on some of their longest and most daring voyages of discovery, such as to the Hawaiian Islands, Easter Island, and possibly the mainland of South America.

Around the fourth century (Kirch, 1985), a double-hulled voyaging canoe set course north from the Marquesas Islands (Fig. 2). Powered by wind in woven-mat sails, the vessel carried with it all the materials necessary to establish a permanent colony in a new land. On board were 20 to 30 people; 27 horticultural plants (Table 1); three domestic animals [the pig (Sus scrofa L.), dog (Canis familiaris L.), and chicken (Gallus gallus L.)]; and a stowaway, the Pacific rat (Rattus exulans L.).

The Hawaiian Islands are geographically one of the most remote places on our planet. The northward voyage covered $4000 \mathrm{~km}$ and probably required 4 to 8 weeks. The area traversed is an empty ocean with no islands, poor fishing, and the threat of being becalmed in the doldrums. The discovery and settlement of Hawaii ranks as one of the epic feats in the history of humanity.

The ancient Polynesian navigators used a technique based on stars and natural signs that recently has been termed "wayfinding" (D.L. Travers, personal communication). They preferred double-hulled canoes for long-distance voyaging because of their greater stability and carrying capacity (Finney, 1979). The broad central platform between the hulls provided a large and dry area to shelter people, plants, animals, and food supplies. Water was carried in gourds and sections of bamboo. Although the construction methods for the canoes used stone-age technology, the hull designs were very sophisticated-akin to the design of a modern airplane wing (D.L. Travers, personal communication).

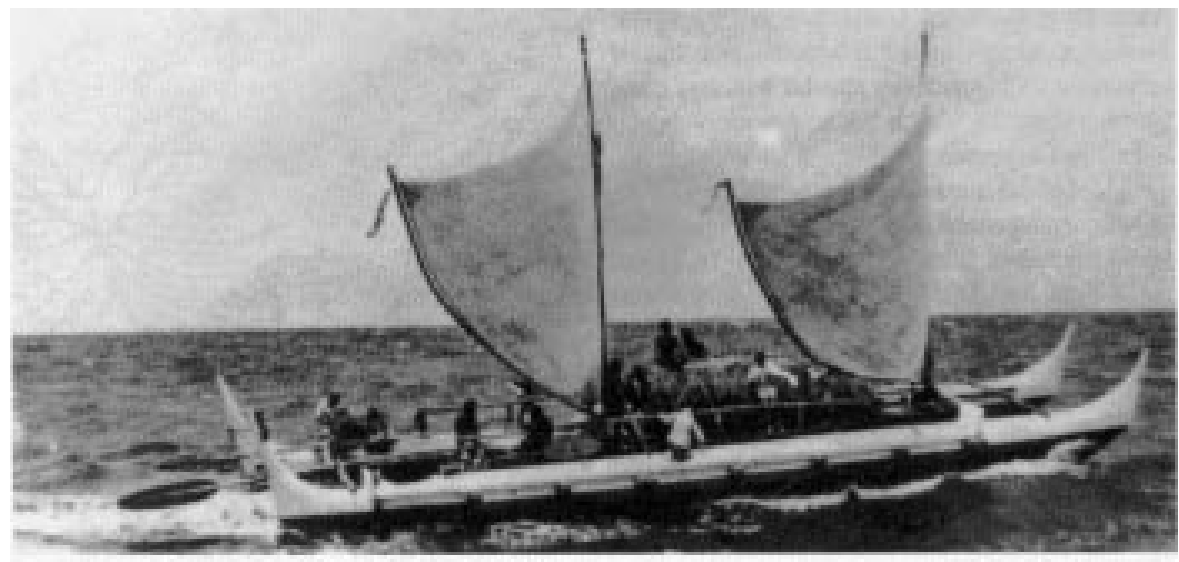

Fig. 2. Polynesian navigators, using a double-hull sailing canoe, such as the replica Hokule'a, transported 27 horticultural plants with them in their voyage of discovery of the Hawaiian Islands. [Photograph reproduced from Lindo and Mower (1980).]

Table 1. Plants introduced to the Hawaiian Islands by Polynesian voyagers.

\begin{tabular}{|c|c|c|c|}
\hline \multicolumn{3}{|r|}{ Names } & \multirow[b]{2}{*}{ Primary use } \\
\hline Common & Hawaiian $^{z}$ & Scientific $^{y}$ & \\
\hline Candle nut & Kukui & Aleurites moluccana (L.) Willd. & Illumination, wood \\
\hline Elephant ear & 'Ape & Alocasia macrorrhiza (L.) G. Don & Famine food \\
\hline Breadfruit & 'Ulu & Artocarpus altilis (Parkinson) Fosberg & Food/wood \\
\hline Paper mulberry & Wauke & Broussonetia papyrifera (L.) Vent. & Clothing, cordage \\
\hline Alexandrian laurel & Kamani & Calophyllum inophyllum L. & Wood \\
\hline Coconut & $\mathrm{Niu}$ & Cocos nucifera $\mathrm{L}$. & Food, cordage, thatch \\
\hline Taro & Kalo & Colocasia esculenta (L.) Schott & Staple food \\
\hline --- & Kou & Cordia subcordata Lam. & Wood \\
\hline $\mathrm{Ti}$ & $\mathrm{Ki}$ & Cordyline fruticosa (L.) Chev & Container, clothing \\
\hline Turmeric & 'Olena & Curcuma longa $\mathrm{L}$. & Dye, medicine \\
\hline Greater yam & Uhi & Dioscorea alata L. & Food \\
\hline Bitter yam & Hoi & Dioscorea bulbifera L. & Famine food \\
\hline Five-leaved yam & Pi’a & Dioscorea pentaphylla $\mathrm{L}$. & Famine food \\
\hline Tiare & --- & Gardenia taitensis DC. & Adornment, medicine \\
\hline Sweetpotato & 'Uala & Ipomea batatas L. & Staple food \\
\hline Bottle gourd & Ipu & Lagenaria siceraria (Molina) Standl. & Container \\
\hline Indian mulberry & Noni & Morinda citrifolia $\mathrm{L}$. & Medicine, famine food \\
\hline Banana & Mai'a & Musa spp. L. & Food, container \\
\hline Kawa & 'Awa & Piper methysticum Forst. f. & Mild narcotic drink \\
\hline Sugar cane & Ko & Saccharum officinarum $\mathrm{L}$. & Food, thatch \\
\hline Polynesian bamboo & 'Ohe & Schizostachyum glaucifolium (Rupr.) Munro & Container, wood \\
\hline--- & --- & Solanum viride Forst. f. ex Spreng & Adornment \\
\hline Mountain apple & Ohi'a ‘ai & Syzygium malaccense (L.) Merr. \& Perry & Food, wood \\
\hline Arrowroot & Pia & Tacca leontopetaloides (L.) Kuntze & Famine food \\
\hline Fish poison tree & 'Auhuhu & Tephrosia purpurea (L.) Pers. & Fish poison \\
\hline Pacific rose wood & Milo & Thespesia populnea (L.) Sol. ex Correa & Wood \\
\hline Wild ginger & Awapuhi & Zingiber zerumbet (L.) J.E. Smith & Adornment, medicine \\
\hline
\end{tabular}

zPukui and Elbert (1986).

y'Whistler (1991).

Present archaeological interpretation (Finney, 1979; Kirch, 1985) suggests that this initial voyage to Hawaii may have been the only northward migration from the Marquesas and that Hawaiian society then developed in isolation until contacted in A.D. 1778 by the noted English navigator and explorer Captain James Cook. There is some evidence, arising from oral traditions among the Hawaiians, that, around the 12th century, there was a period of two-way voyaging between Hawaii and Tahiti. This assertion is not well documented.

\section{PLANTS IN THE HORTICULTURAL ASSEMBLAGE}

Among the wide range of plant types on board the canoe (Table 1), the most prevalent were herbaceous species with edible roots or tubers and trees that yielded fruit or nuts. The assemblage contained five important staples of the Pacific islanders: taro (Fig 3.), sweetpotato, yam, breadfruit, and banana. Also present was the tree referred to in the Pacific as the "staff of life"- the coconut palm (Abbott, 1992). As discussed earlier, most of the assemblage originated in Southeast Asia, either the mainland or associated islands. There was one important exception - the sweetpotato, whose origin lies in South America. Yen (1971) suggests that the navigators, before their departure from the Marquesas north to Hawaii, completed a two-way voyage to the mainland of South America, during which they acquired the sweetpotato. Interestingly, the assemblage contained nocereal crops. Although rice (Oryza sativa L.) and millet were grown in Southeast 
Asia, they were not cultivated in Polynesia. This is an intriguing point because rice can be produced with practices similar to those used for taro (Fig. 3), which became widely established in Polynesia.

Most of the horticultural assemblage (Table 1) was transported as vegetative propagules, such as cuttings, tubers, slips, or suckers. These were first swathed in freshwater-moistened moss, then swaddled in dry leaves, kapa, or bark cloth, or skin from the banana tree (Holmes, 1981). Finally, these bundles were put in a casing of woven mats and hung from the roof of the canoe's hut where they would be protected from saltwater spray.

During a voyage from Hawaii to Tahiti (Fig. 2), Hokule'a, a modern replica of a Polynesian voyaging canoe (Lindo and Mower, 1980), attempted to transport the same plant assemblage the Polynesians originally brought to Hawaii (Holmes, 1981). The effort was partially successful. Some plants died, while others survived and were planted upon arrival in Tahiti (Holmes, 1981). These mixed results underscore the difficulty of transporting planting material over vast distances and under extreme environmental conditions.

\section{IMPACT OF HORTICULTURE ON ISLAND ENVIRONMENT}

The Polynesian discoverers found the Hawaiian Islands to be volcanic, surrounded by coral reefs, with a subtropical climate and a natural ecosystem that had evolved over several million years in the absence of people (Fosberg, 1991). Prevailing northeastern tradewinds shaped windward and leeward sides of the islands. The former were characterized by high rainfall, permanent streams, and rain forests; while the latter were arid with dryland forests. The indigenous flora of the islands consisted of few edible plant species (Fosberg, 1991). Edible bird and marine species, however, were abundant.

The first colonists settled at the mouths of windward valleys, such as Kahana Bay on Oahu. This high-rainfall environment most resembled their former homes in the Marquesas and would be most likely to accommodate the plants they transported. After their plants were established, the settlers began to emphasize taro cultivation for food production. A taro plant (Fig. 3) produces 10 shoots or suckers during a typical crop cycle of 12 to 15 months (C. Reppun, personal communication). The shoots can be separated from the mother plant to start new plants. By my calculation, taro production would have been sufficient to support the colony 3 years after the initial planting of propagules transported by the voyagers. During the first 3 years, the settlers must have relied on the marine environment for a diet of fish, shellfish, seaweed, and marine mammals. Birds were also an important source of food. Thereafter, the yield of horticultural crops, such as taro and sweetpotato, increasingly formed the basis of the Hawaiian diet.

The introduction of the Polynesians' horticultural assemblage had a dramatic impact on the island environment (Fosberg, 1991). The

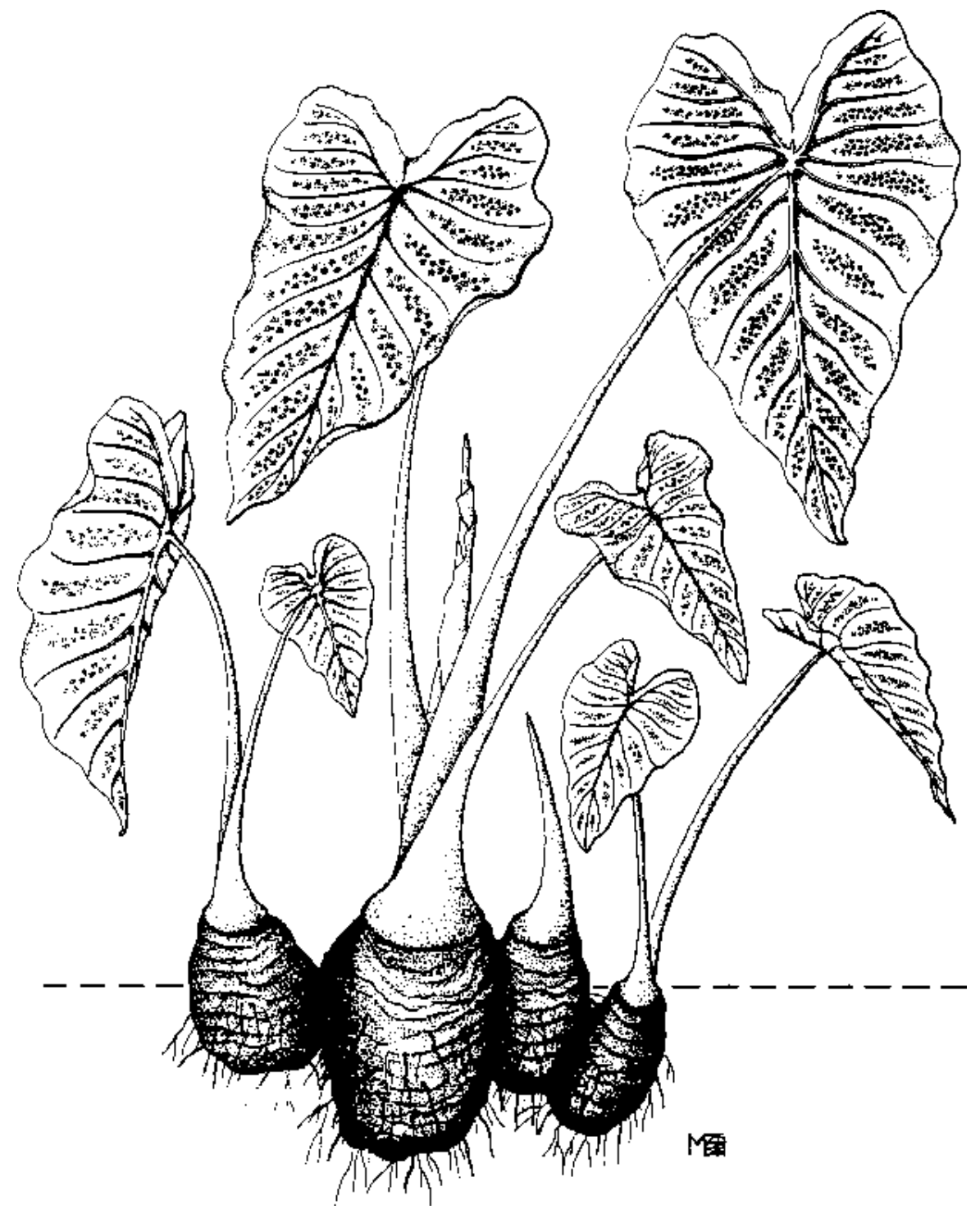

Fig. 3. The staple food of traditional Hawaiian society was taro or kalo (Colocasia esculenta). The corm or underground portion was mashed and eaten as a paste called "poi." Large, irrigated, terrace systems were developed for taro production. [Figure adapted from Abbott (1992).]

ecological balance that had been achieved during several million years of isolation was severely disrupted. The settlers used fire as a tool in clearing land for planting. Much of the lowland vegetation was replaced by introduced flora. Native forests were converted to tree gardens on the windward sides and grasslands on the leeward sides. Windward valleys were transformed first into shifting gardens, then into irrigated field systems for taro culture.

Beggerly (1990) reconstructed the introduction of horticulture by Polynesian voyagers to Kahana Valley on windward Oahu. Before settlement, the vegetation was a stable forest. The early colonists used slash-andburn techniques to establish their crops. This technology deforested the slopes of the lower valley and began the conversion of forest to grassland. The denuded slopes were exposed to erosion and the virgin soils were carried into the bay, which was transformed into an alluvial plain. This action damaged the marine habitats that had provided shellfish and other marine foods to the colonists. Beggerly (1990) believes that repeated burning eventually resulted in a massive ecosystem disturbance. Confronted with an environmental disaster, the settlers abandoned the valley and relocated to another windward valley. Not all archaeologists share Beggerly's interpretation that the environmental impact of horticulture resulted in the abandonment of a windward valley, but there is general agreement that the impact was dramatic and damaging.

The fossil evidence showing the extinction of numerous endemic birds is the most enduring evidence for the theory that environmental disturbance followed the arrival of the Polynesians (Kirch, 1985). Likely, well over half of the species of endemic land birds that were present in the archipelago before the arrival of the Polynesians became extinct as the Hawaiian civilization became established (Olson and James, 1982).

For unknown reasons, the Hawaiians abandoned the Polynesian tradition of long-distance voyaging (Finney, 1979). Captain Cook 
reported seeing only coastal craft in his initial accounts of European contact with the Hawaiians. However, the Hawaiians did strengthen and expand the horticultural base of their society. Their population grew to 300,000 and spread over the islands' lowlands. They adapted and developed their horticultural techniques and intensified their crop production. At the time of European contact, numerous varieties of the major crops were observed. For example, there were 300 named varieties of taro (C. Reppun, personal communication). Handy and Handy (1972) suggest that this is evidence the Hawaiians had mastered techniques for plant improvement. It is certain that the Hawaiians achieved a level of agricultural production unrivaled elsewhere in Oceania (Kirch, 1985). The irrigated field systems for taro production, in particular, demonstrated high levels of social organization and engineering skills.

The ancient Polynesians have long been recognized as explorers and colonists of the Pacific Islands, but they also deserve recognition as horticulturists for developing a complex civilization in the Hawaiian Islands based on the production of horticultural crops.

I hope that when future historians of our discipline chronicle the development of horticulture, they will look to Southeast Asia and the Pacific Islands and include the prehistoric exploits of fishers who domesticated an important assemblage of tropical plants, the daring Polynesian navigators who dispersed them over a sizeable portion of the globe (long before Europeans were sailing out of sight of land), and the ancient Hawaiians who developed irrigated field systems for the intensive production of horticultural crops.

\section{Literature Cited}

Abbott, I.A. 1992. La'au Hawaii: Traditional Hawaiian uses of plants. Bishop Museum Press, Honolulu.

Beggerly, P.P. 1990. Kahana Valley, Hawaii: A geomorphic artifact. PhD Diss., Univ. of Hawaii, Honolulu.

Bellwood, P. 1987. The Polynesians: Prehistory of an island people. Thames \& Hudson, London.

Chang, K.C. 1976. Early Chinese civilization: Anthropological perspectives. Harvard Univ. Press, Cambridge, Mass.

Finney, B.R. 1979. Voyaging, p. 323-351. In: J.D. Jennings (ed.). The prehistory of Polynesia. Harvard Univ. Press, Cambridge, Mass.

Fosberg, R.F. 1991. Polynesian plant environments, p. 11-23. In: P.A. Cox and S.A. Banack (eds.). Islands, plants, and Polynesians: An introduction of Polynesian ethnobotany. Dioscorides Press, Portland, Ore.

Halfacre, R.G. and J.A. Barden. 1979. Horticulture. McGraw-Hill, New York.

Handy, E.S.C. and E.G. Handy. 1972. Native plant- ers in old Hawaii: Their life, lore, and environment. Bishop Museum Bul. 233. Honolulu.

Holmes, T. 1981. The Hawaiian canoe. Editions Limited, Honolulu.

Irwin, G. 1992. The prehistoric exploration and colonization of the Pacific. Cambridge Univ. Press, Cambridge, U.K.

Janick, J. 1979. Horticultural science. 3rd ed. W.H. Freeman \& Co., Chicago.

Jennings, J.D. 1979. The prehistory of Polynesia Harvard Univ. Press, Cambridge, Mass.

Kirch, P.V. 1985. Feathered gods and fishhooks. Univ. of Hawaii Press, Honolulu.

Lindo, C.K. and N.A. Mower(eds.). 1980. Polynesian seafaring heritage. Kamehameha Schools Press, Honolulu.

Olson, S.L. and H.F. James. 1982. Prodromus of the fossil avifauna of the Hawaiian Islands. Smithsonian Inst. 365. Washington, D.C.

Pukui, M.K. and S.H. Elbert. 1986. Hawaiian dictionary. revised ed. Univ. of Hawaii Press, Honolulu.

Solheim, W.G. 1972. Northern Thailand, Southeast Asia, and world prehistory. Asian Perspectives 13:145-162.

Whistler, W.A. 1991. Polynesian plant introductions, p. 41-66. In: P.A. Cox and S.A. Banack (eds.). Islands, plants, and Polynesians: An introduction to Polynesian ethnobotany. Dioscorides Press, Portland, Ore.

Yen, D.E. 1971. The development of agriculture in Oceania, p. 1-12. In: R.C. Green and M. Kelly (eds.). Studies in oceanic culture history: Vol. 2. Bishop Museum, Honolulu. 


\section{Insert full-page LI-COR ad here (negative enclosed)}

This is p. 1230-NO FOLIO 